Lo Bianco, Joseph (1996) Institutional Responses: Empowering Minority Children. TESOL

Quarterly 30(3), 586-590.

\title{
Institutional Responses: Empowering Minority Children
}

\author{
Joseph Lo Bianco \\ National Language and Literacy Institute of Australia
}

In Australia and possibly in many other countries, a very contradictory pattern has been emerging in recent years. TESOL educators who believe in the possibility of empowering minority children within existing educational institutions have often seen the related and contributory need for multicultural and bilingual education. This belief is by no means universally shared among educators. Indeed I would argue that the dominant way of thinking about the project of educational empowerment has dramatically changed from an optimistic one to a pessimistic one.

However, global trends may provide some hope that schooling can validate ESL children's L1s and cultures. The problem extends into policies for the education of minority children that name, frame, and orient teaching and assessment practices in particular ways according to how they constitute the learners and the task of the system. These policies gravitate between sometimes stressing the autonomous power of schooling to affect life chances and at other times stressing the dependence of schooling on wider social forces. This oscillation is an analogue of the deeper sociological tension between attributing change to human agency and stressing the effects of established structure and interests.

\section{Theories of Empowerment}

Empowerment theories seek to make ESL children more powerful, but can ESL learners be constituted this way within ESL alone? The empowerment model is best represented in the work of Cummins (1986) and the ideologies of minority language rights (Skutnabb-Kangas, 1995) but also in various forms of either pluralism or multiculturalism. Cummins's (1994) model represents the most coherent and elaborated schema of empowerment. Recently he has sought to redefine empowerment as "collaborative creation of power" (p. 54) in which issues of language and cultural development are critical.

The commendable wholeness of the approach to the education of L2 children supported by Genesee (1994) will be only partial as long as schools cannot nourish the process of intellectualising the child's L1 (the primary initial vehicle for conceptualisation). Otherwise schools produce "squandered bilinguals." Curricula rarely offer studies that build on diversity as a resource and rarely give prestigious recognition to the knowledge and culture of language minority children.

\section{Globalisation's Effects}

It is interesting for teachers as much as for anyone else to speculate on the possible effects on ESL learners of what is coming to be termed globalisation. The term is used to mean the collective effects of international economic interdependence (the emergence of a "world system" with its primary rationality being competitiveness in markets), instantaneous and uncontrolled communications, population mobility at unprecedented levels (the "commodification" of education, labour mobility, and elite executives), and the transfer of trading and financial power away from predominantly Englishspeaking cultures towards non-English-speaking ones. One effect is the emergence virtually everywhere of multicultural societies, bringing with them the problem of managing difference. At the same time the decline of the Anglo-American ascendancy of the postwar period is making Englishspeaking societies more conscious of a pragmatic purpose in promoting the teaching of (some) languages other than English and in offering cultural awareness programs for their school populations. Globalisation demands educational responses. Connections between the knowledge and skills of language minority children and the newly perceived importance of cultural and language learning for reasons of exploiting economic and trading opportunities could add fresh impetus to pluralistic curricula. Alternatively, without principled connections between these two demands on curricula, globalisation will further characterise what language minority children know, or potentially know, as marginal and irrelevant, nurturing assimilationist agendas for them while curricula encourage 
elite pluralism for majority children.

\section{Knowledgeable Children}

Only with integrated pluralistic curricula could schooling treat language minority children as knowing learners - learners whose existing stocks of knowledge, experiences, and skills might productively be incorporated into developmentally appropriate instructional programs. Mainstream curricula in many parts of the world (e.g., Reggio Emilia, 1987) conceive of the learner as active and powerful (as a knower); extending these notions to language minority children ought to draw on mainstream demand for cross-cultural perspectives to pervade curricula for reasons of perceived national economic interest.

\section{Pluralist Policies}

Pluralist positions seek to completely reconceptualise the social domain to give a central place to difference and thereby to elevate the cultural and linguistic knowledge of language minorities as a positive resource, as diverse cultural capital. There are at least two forms of pluralism: the structural and the culturalist. They diverge on whether empowerment is achievable through language and cultural programs in schools. The former holds that multicultural policies are likely to fail because they naively ascribe to educational institutions the transformative power that resides elsewhere in society, whereas culturalist explanations of the educational inequalities faced by language minority children attribute these inequalities to the cultural and linguistic dissonance between home and school (Banks, 1986).

\section{Global Trends and New Communication Modes}

Those who support cultural pluralism in Western education have always done so with the internal diversity of society in mind, often advocating the rights of minorities in these societies. But current global tendencies and developments in the economic, civic, and personal spheres of life of the contemporary world add powerfully to the need for pluralist education.

These tendencies are highly diverse. A powerful longer term trend is the move towards the creation of political structures that aggregate ethnic and national cultures (i.e., emerging political structures based on economic interest and geographic proximity). The European Union (EU), the Asia Pacific Economic Cooperation group, and the North American Free Trade Agreement are examples of this trend at different levels of development. Portuguese-speaking children in Luxembourg are in the ambiguous position of shifting from being speakers of an immigrant language to being co-citizens speaking an EU official language. Another example is the massive movement of population in all parts of the world and the emergence virtually everywhere of multicultural societies (Castles \& Miller, 1993).

More subtly, semiotic systems have multiplied inexorably such that communication increasingly draws on diverse modes of meaning making and integrates them with complex technologies. Communication is becoming multimodal as it integrates the visual, the gestural, the spatial, the graphic, and the electronic (delayed-recorded and instantaneous) with the traditional modes of written and spoken forms of language (Luke, 1995; Michaels, 1995). Music videos are a good case in point, requiring a sophisticated "reading" skill.

Also, globalisation is yielding unique, hybrid forms of language and culture as speakers of different mother tongues must interact in linguae francae that are not native to the any of those using the common language. Economic/trading wealth and power have also been dispersed among groups and societies (in north Asia especially) less identified with English-speaking modernity than at any time in the recent past (Lo Bianco, 1995).

\section{Will Pluralistic Education Advantage Minorities?}

These changes may constitute new and effective arguments for bringing cultural and linguistic diversity centrally into the domain of curriculum. For this to happen effectively will require a major renaming of the task of teaching children whose languages and cultural backgrounds are not the same as the dominant ones of the society they reside in. But in most Western societies schooling reform has fallen on hard times (Lingard, Knight, \& Porter, 1993) - the mood for empowerment is sombre, if not pessimistic; the resources are fewer, the ideology less hopeful. If the renewed interest in self-serving cultural studies in English-speaking nations seriously materialises, ESL educators will need to actively construct an interdependence between such learning and minority children's existing and potential knowledge to prevent their further marginalisation. If this is successfully done, then 
institutional response to global trends may well be capable of empowerment.

\section{The Author}

Joseph Lo Bianco is the Chief Executive of the National Languages and Literacy Institute of Australia and the author of the 1987 National Policy on Languages, the first official language policy for Australia and the basis of federal and other state policies. He has edited and written books on issues related to language and cultural education and is a frequent speaker on these topics. His main areas of interest are international language planning, the social and intellectual effects of bilingualism and bilingual education, language politics, and multilingualism and public policy.

\section{References}

Banks, J. A. (1986). Multicultural education, development, paradigms, and goals. In J. A. Banks \& J. Lynch (Eds.), Multicultural education in Western societies (pp. 2-29). New York: Holt, Rinehart \& Winston.

Castles, S., \& Miller, M. J. (1993). The age of migration: International population movements in the modern world. London: Macmillan.

Cummins, J. (1986). Empowering minority students: A framework for intervention. Harvard Educational Review, 56, 18-36.

Cummins, J. (1994). Knowledge, power, and identity in teaching English as a second language. In F. Genesee (Ed.), Educating second language children: The whole child, the whole curriculum, the whole community (pp. 33-58). Cambridge: Cambridge University Press.

Genesee, F. (Ed.). Educating second language children: The whole child, the whole curriculum, the whole community (pp. 33-59). Cambridge: Cambridge University Press.

Lingard, B., Knight, J., \& Porter, P. (Eds.). (1993). Schooling reform in hard times. London: Falmer Press.

Lo Bianco, J. (1995). Multilingualism, education and the new notion of nation. In C. le Roux (Ed.), Proceedings of the 15th Annual Conference of the Southern Africa Applied Linguistics Association: Constitutionally enshrined multilingualism: Challenges and responses (pp. 1-33). Stellenbosch, South Africa: Southern Africa Applied Linguistics Association.

Luke, C. (1995). Multimedia: Multiliteracies. Education Australia, 30, 14-18.

Michaels, S. (1995). Literacy as reasoning within multiple discourses. Education Australia, 30, 2023.

Reggio-Emilia, C. (1987). I cento linguaggi dei bambini [The hundred languages of children]. Emilia Romagna, Italy: Department of Education.

Skutnabb-Kangas, T. (1995). Introduction. In T. Skutnabb-Kangas (Ed.), Multilingualism for all (pp. 17). Lisse, Netherlands: Swets \& Zeitlinger. 


\section{University Library}

\section{- M M I N E R VA A gateway to Melbourne's research publications}

Minerva Access is the Institutional Repository of The University of Melbourne

Author/s:

LoBianco, J

Title:

Institutional responses: Empowering minority children

Date:

1996-09-01

Citation:

LoBianco, J. (1996). Institutional responses: Empowering minority children. TESOL QUARTERLY, 30 (3), pp.586-590. https://doi.org/10.2307/3587700.

Persistent Link:

http://hdl.handle.net/11343/116670 